\title{
Fiscal Deficit Episode in Nigeria: What Is the Percentage of Error Correction between Public Revenue and Expenditure?
}

\author{
Dauda Gbolagade Adebisi ${ }^{1}$, Olusola Joel Oyeleke ${ }^{2 *}$ \\ ${ }^{1}$ Department of Accounting and Finance, Bowen University, Iwo, Nigeria \\ ${ }^{2}$ Department of Economics, Redeemer's University, Ede, Nigeria \\ Email: dgadebisi@yahoo.com, ^oyelekeolusola1@gmail.com, ^oyelekej@run.edu.ng
}

How to cite this paper: Adebisi, D. G., \& Oyeleke, O. J. (2020). Fiscal Deficit Episode in Nigeria: What Is the Percentage of Error Correction between Public Revenue and Expenditure? Modern Economy, 11, 533-540. https://doi.org/10.4236/me.2020.112039

Received: December 12, 2019

Accepted: February 22, 2020

Published: February 25, 2020

Copyright (๑) 2020 by author(s) and Scientific Research Publishing Inc. This work is licensed under the Creative Commons Attribution International License (CC BY 4.0).

http://creativecommons.org/licenses/by/4.0/ (c) (i) Open Access

\begin{abstract}
In the last three decades, almost every year except 1995 and 1996 respectively, fiscal operations of government in Nigeria have been ended in deficits. This paper determines the percentage of error correction between government revenue and expenditure in Nigeria from 1980-2018. Secondary data sourced from Central Bank of Nigeria, 2018, are analysed. Augmented-Dicky-Fuller (ADF) unit root test is used to examine the properties of the variables. Using Engel-Granger 2-step procedure to assess cointegration, error correction technique of estimation employed provides interesting results. The findings reveal that it takes two years and five months, approximately $42 \%$ as speed of adjustment, for the variables to be at equilibrium, the development that makes fiscal deficit inevitable in Nigerian economy. To widen the scope of revenue generation, it is, therefore, pertinent for authorities to ensure that investments are undertaken to close the gap between revenue and expenditure within the shortest time possible.
\end{abstract}

\section{Keywords}

Fiscal Deficit, Expenditure, Error Correction, Revenue

\section{Introduction}

Theoretical economic literature on growth and development emboldens authorities of developing economies to embark on fiscal deficits so as to stimulate steady economic growth process and particularly, bail the economy out of recession (Archibald \& Greenidge, 2003). However, experience have shown that huge and perpetual fiscal deficits have been accompanied by large debts, high interest 
rates and inflation in most of transition economies particularly in Latin America and sub-Saharan Africa (Tshiaswak-Kashalala, 2006). Moreover, in recent years, accumulated budget deficits overtime have led to public debts reaching its highest level in economies around the world, making public debts a worldwide issue. The development situates economies under serious financial pressure and threatens the fiscal sustainability of many nations, including Nigeria (Oyeleke \& Ajilore, 2014). Fiscal deficit occurs when revenue generated by government of a country falls short of its expenditure in a fiscal year.

In the last three decades, almost every year except 1995 and 1996 respectively, fiscal operations of government in Nigeria have been ended in deficits. For instance, in 1980, while government revenue was 12.993 billion, expenditure stood at $\$ 14.923$ billion, making deficit of $\$ 1.975$ billion. Also, in 1990, when total revenue generated in the economy of Nigeria, including oil sales, was $\$ 38.152$ billion, the expenditure incurred was $\$ 60.268$ billion and the deficit had increased to $\$ 22.116$ billion. As at the beginning of another decade, i.e. year 2000, the discrepancy between government revenue and expenditure has become worrisome in Nigeria. In the same year 2000, while government proposed to spend $\$ 597.282$ billion, $\$ 701.059$ was estimated to cover both recurrent and capital expenditure. Lastly, in 2018, total government was 4185.64 trillion and expenditure was $\$ 713.74$ trillion, leaving the balance of $\$ 3628.10$ trillion as deficit.

The recurring experience has been the product of dwindling revenue generation as opposed to perpetual increase in expenditure profile of government, thus, making the incidence of fiscal deficits unavoidable (Ezeabasili \& Mojekwu, 2011). Fiscal deficit is becoming problematic in Nigeria as private investors are no longer willing to hold nation's debts when they become more increasingly convinced that government may either default or monetise the debts by printing more money (seignoirage) to reduce the existing real debt's value. Then, the development portends strong macroeconomic instability for the economy. Therefore, with the existing debt profile of Nigeria, economists and policy makers have begun to exercise worry over the persistent decline in revenue generation and upsurge in public spending in the economy of Nigeria.

Although, studies have investigated causality between government revenue and expenditure to assist the policy makers in ascertaining which variable particularly causes the other. Again, studies have investigated the sustainability of fiscal policy in Nigeria to determine if the economy has violated intertemporal budget constraint equation (see Oyeleke \& Ajilore, 2014; Oshikoya \& Tarawale, 2010). Also, to determine whether weak or strong, some research works have verified the strength of relationship between public revenue and expenditure in Nigeria. However, as its objective, no empirical work known to us has determined the number of years or the speed of adjustment to revert to equilibrium whenever there is shock to either public revenue or expenditure. This has been the focus of this paper. The rest of the paper is organised as follows: empirical review is covered in section two, the data and model specifications are presented in section three, while estimation techniques in section four. Results and discus- 
sion are covered in section five and conclusion of the study is presented in section six.

\section{Empirical Review}

Most existing empirical studies concentrate on fiscal policy sustainability for various countries. For example, Nwakwe (2008) analysed the government finances for Italy to determine if the economy's fiscal policy satisfies the Inter-temporal Budget Constraint (IBC) since post-Maastricht period. The author tested for stationarity, cointegration and structural breaks in the debt to GDP annual series, government revenue and expenditure quarterly series for the period 1962 to 2004. The results showed that the finances of Italy were sustainable, though the government revenue and expenditure were weak form of sustainability. Lusiyan \& Thornton (2009) investigated the long-run fiscal sustainability in South Africa by applying a battery and recently developed unit root and cointegration tests to real revenue and expenditure data for the period 1895 to 2005. After allowing for structural breaks, there was evidence that South Africa revenue and expenditure were cointegrated and that the economy was in the long-run weakly sustainable. Kuncoro (2011) examined the sustainability of the fiscal budget of Indonesia. His empirical estimates were achieved through several econometric methods of unit root, cointegration and VAR (vector auto regression). The findings showed that the fiscal policy of the economy was sustainable.

Similarly, Doh-Nani (2011) evaluated budget deficit sustainability of Ghana between 1960 and 2007, using present value budget constraint approach. The author employed stationarity and cointegration tests on both government expenditure and revenue. It was found that both government expenditure and revenue of Ghana were stationary and that cointegration test favoured the sustainability of budget deficit of Ghana. He concluded that the budget deficit of Ghana was sustainable over the entire studied period. Saad (2011) explored the sustainability of public debts in Lebanon over the period 1965 to 2008, applying the intertemporal budget constraint model. The analyses involved unit root and cointegration tests of ratio of revenue and expenditure to GDP. The results showed that Lebanese public debt seemed to be weakly sustainable. Other authors that have worked on fiscal policy sustainable include Oyeleke \& Ajilore (2014) for Nigeria, Collingnon (2012) for Europe, Adams et al. (2010) for Developing Asia, Jibao et al. (2012) for South Africa, and Quintos (1995) for US economy.

\section{Gap in Existing Literature}

It is obvious, given the empirical literature reviewed above, that there is possibly no empirical studies devoted to investigating the percentage of error correction between government revenue and expenditure in Nigeria, which is the objective of this study. Knowing the percentage of error correction with which government revenue variable is adjusting to attain equilibrium with government ex- 
penditure would provide the policy makers with information on how economy is fast or slow to move out of current debts profile. With this objective, the study employs Error Correction Model (ECM) to determine the percentage of error correction between government revenue and expenditure in Nigeria.

\section{Data and Model Specification}

The data used in this study are annual time series comprising of government revenue and government expenditure expressed as fractions of GDP for the period 1980 to 2018. The data are sourced from Central Bank of Nigeria Statistical Bulletin, 2018 issue. This study adopts transversality condition equation used in Oyeleke \& Ajilore (2014) to model equilibrium condition, though with different objective. To specify the budget constraint which is the equilibrium condition for revenue and expenditure variables, we begin the model as;

$$
G_{t}=\alpha+R_{t}+\lim \frac{B_{t+j}}{(1+r)^{j+i}}+\varepsilon_{t}
$$

If limit term in Equation (1) approaches zero, we obtained the equation below, thus, the model is specified in form:

$$
R_{t}=\alpha+\beta G_{t}+\mathcal{E}_{t}
$$

where $R_{t}$ is the government revenue, $\alpha$ is the intercept which shows the degree of autonomous drift in the parameters. $\beta$ represents the slope of the equation that shows the extent to which variations in government expenditure affects the value of government revenue, $G_{t}$ is the government expenditure and $\mathcal{E}_{t}$ is the error term.

\section{Empirical Results}

\subsection{Unit Root Test}

To determine the percentage of error correction back to equilibrium whenever there is shock to either government revenue or government expenditure over the period under review, which is the focus of this paper, the following steps are taken: we first test for the stationarity and order of integration of government revenue and government expenditure to ensure that either of the variables is not I(2). Thereafter, we test for cointegrating relationship between the variables and finally estimate the short-run nexus between government revenue and expenditure, using error correction model (ECM) to determine the speed of adjustment between the two variables.

In the first step, we employ only one technique of unit root test of Augumented Dickey \& Fuller (1979) to ascertain the stationarity and order of integration of government revenue and expenditure. Table 1 presents the results of unit root tests.

From Table 1, results show that the variables are I(1) process, hence we move on to testing for long run relationship between government revenue and expenditure variables. To achieve this aim, Engel-Granger 2-step approach is adopted, since the variables are just two in the model. 
Table 1. Unit root test results.

\begin{tabular}{ccc}
\hline \multirow{2}{*}{ Variable } & \multicolumn{2}{c}{ ADF } \\
\cline { 2 - 3 } & Level & First Difference \\
\hline LREV/GDP & -1.166732 & $-7.903747^{\star}$ \\
LEXP/GDP & -1.623642 & $-10.22734^{*}$ \\
\hline
\end{tabular}

Note: ${ }^{\star}$ and ${ }^{\star * \star}$ denoted $1 \%$ and $10 \%$ significance levels respectively based on Mackinnon critical values.

\subsection{Cointegration Test}

The next step that follows is cointegration test, using Engle-Granger 2-step method (Engle \& Granger, 1987). Engle-Granger 2-step cointegration is used because the test estimates the long-run relationship between variables even with different orders of integration. According to Doh-Nani (2011), the reliable coefficients of the model could be obtained. As the name indicates, two procedures are involved; we first run OLS regression and then generate the residuals from OLS estimated results. The step that follows is testing the residuals generated from OLS estimated results against presence or otherwise of unit root. According to Brooks (2008), if the residuals are stationary at level, i.e. their order of integration is $I(0)$, then the variables are said to be cointegrated, but if not, they are non-cointegrated. Given that the variables in this model are expressed as a percentage of GDP, to estimate OLS model which must be linear and stationary at levels, Equation (1) is re-specified in the model below:

$$
\left(\frac{\mathrm{REV}}{\mathrm{GDP}}\right)_{t}=\alpha+\beta\left(\frac{\mathrm{EXP}}{\mathrm{GDP}}\right)_{t}+\mathcal{E}_{t}
$$

Table 2 presents OLS regression results from which residuals of the series are generated.

To determine if there is cointegration between government revenue and expenditure, having generated the residuals from OLS regression estimates in $\mathrm{Ta}-$ ble 2, the residuals are tested for stationarity or presence of unit root, using ADF unit root test. The results are pasted in Table 3. Results from both tests confirm that the residuals are stationary at level, implying that

There is cointegration or long-run relationship between government revenue and expenditure in Nigeria over the period review.

\section{Results and Discussion}

Finally, short-run association between government expenditure and revenue for the period under review is estimated with error correction model. Since cointegration is established between government revenue and expenditure, short-run analysis is undertaken to determine the percentage of error correction between the variables of interest. It is equally important to note that the technique (ECM) is capable of presenting corresponding error correction representation. Also, the technique helps to confirm the existence of long-run association between the variables because variations in public revenue is not influenced by 
Table 2. OLS results.

\begin{tabular}{ccccc}
\hline Variable & Coefficient & Std. Error & t-Statistic & Prob. \\
\hline GTE & 0.683984 & 0.087703 & 7.798906 & 0.0000 \\
C & 0.004096 & 0.007892 & 0.519024 & 0.6069 \\
R-squared & 0.628187 & F-statistic & 60.82294 \\
Adjusted R-squared & 0.617859 & Prob(F-statistic) & 0.000000 \\
S. E. of regression & 0.014149 & Durbin-Watson stat & 0.759857 \\
\hline
\end{tabular}

Table 3. Residual based unit root test.

\begin{tabular}{ccc}
\hline \multirow{2}{*}{ Variable } & \multicolumn{2}{c}{ ADF } \\
\cline { 2 - 3 } & Level & First Difference \\
\hline Resid. & $-2.818030^{* * *}$ & \\
\hline
\end{tabular}

Note: ${ }^{*}$ and ${ }^{* * *}$ denoted $1 \%$ and $10 \%$ significance levels respectively based on Mackinnon critical values.

only shocks from public expenditure, but from its own shocks as well and the magnitude of volatility between the levels of both variables. We, therefore, transform Equation (3) into first difference of the variables and re-specify it to include error correction term, hence, the Equation (3) becomes:

$$
\Delta\left(\frac{\mathrm{REV}}{\mathrm{GDP}}\right)_{t}=\alpha+\beta \Delta\left(\frac{\mathrm{EXP}}{\mathrm{GDP}}\right)_{t}+\lambda \mathrm{ECM}_{(-1)}
$$

where $\lambda$ is the coefficient of the error correction term that combines reaction in association between government revenue and expenditure. It, therefore, indicates whether the model is convergent or divergent towards equilibrium. It also denotes the speed of adjustment to equilibrium after the shocks to the system. $\Delta\left(\frac{E X P}{G D P}\right)_{t}$ is the first difference of government expenditure/GDP and $\Delta\left(\frac{\mathrm{REV}}{\mathrm{GDP}}\right)_{t}$ is the first difference of government revenue. $\mathrm{ECM}_{-1}$ is the first-order error correction (residuals) generated from OLS regression estimated in Equation (3). The results of short run regression are presented in Table 4.

The ECM has the correct sign-negative, and it is statistically significant at $1 \%$ significance level, given the value of its t-statistic $(-3.039)$ and the probability (0.005) respectively. This indicates that there exists approximately $42 \%$ i.e. (41.78\%) of error correction back to the equilibrium whenever there is distortion to government revenue in the economy of Nigeria during the period under review. Converting $42 \%$ of error correction to yearly period, it takes government revenue in Nigeria two years and five months to catch up with the movement of government expenditure before there could be equilibrium, i.e. long run relationship between the variables. Though the adjustment is not too slow, yet, government revenue has not been spontaneously adjusting back to its track whenever there is shock to variable over time. This development has been accounted for persistence in deficit finances of government of Nigeria during the period 
Table 4. Short run analysis (ECM).

\begin{tabular}{ccccc}
\hline Variable & Coefficient & Std. Error & t-Statistic & Prob. \\
\hline$C$ & $6.66 \mathrm{E}-05$ & 0.001784 & 0.037300 & 0.9705 \\
$\Delta \ln \mathrm{GTE}$ & 0.552545 & 0.084093 & 6.570677 & $0.0000^{*}$ \\
$\Delta \ln \mathrm{GTE}_{-1}$ & -0.263068 & 0.095634 & -2.750762 & $0.0100^{* *}$ \\
$\Delta$ nn GTE $_{-2}$ & -0.076790 & 0.088337 & -0.869278 & 0.3916 \\
ECM $_{-1}$ & -0.417802 & 0.137478 & -3.039051 & $0.0049^{*}$ \\
R-squared & 0.773536 & F-statistic & 25.61777 \\
Adjusted R-squared & 0.743340 & Prob(F-statistic) & 0.000000 \\
S.E. of regression & 0.010517 & Durbin-Watson stat & 2.123227 \\
\hline
\end{tabular}

${ }^{*} \&{ }^{* *}$ indicate significance level at $1 \%$ and $5 \%$ respectively.

covered by this study. The finding is consistent with the results of Saad (2011) for Lebanon, Oshikoya \& Tarawalie (2010) and Oyeleke \& Ajilore (2014) for Nigeria. The R-square statistic from Table 4 shows that $77 \%$ of the variation occurs to the dependent variable is explained by the explanatory variables in the model. It is equally obvious that the model is free from multicolinearity problem, given the Doubin-Watson statistical value (2.123) of the model that is moderate.

\section{Conclusion}

This paper examined the speed of adjustment between government revenue and expenditure in Nigeria from 1980 to 2018 with sole aim of determining the percentage of error correction with which public revenue was moving behind public expenditure. After examining the stationarity properties of the series, long-run relationship between the variables of government revenue and expenditure was established. To analyse the data, error correction technique of estimation was employed to determine the percentage of error correction between government revenue and expenditure. The findings showed that approximately $42 \%$ $(-0.417 \%)$ was the speed of adjustment with which public revenue was trailing public expenditure for them to be at equilibrium. The implication was that the recovery process between government revenue and expenditure was somehow slow for them to be at equilibrium whenever there was distortion between government revenue and expenditure in the economy of Nigeria during the period under review. From the findings, converting the percentage of error correction into yearly period, it would take government revenue two years and five months to catch up with government expenditure, for both variables to be in equilibrium in Nigeria.

\section{Conflicts of Interest}

The authors declare no conflicts of interest regarding the publication of this paper. 


\section{References}

Adams, C., Ferrarimi, B., \& Park, D. (2010). Fiscal Sustainability in Developing Asia. ADB Economics Working Paper Series No. 205. https://doi.org/10.2139/ssrn.1640264

Archibald, X., \& Greenidge, K. (2003). Debt and Fiscal Sustainability in Barbados. Bridgetown: Central Bank of Barbados, Research Department Publication.

Brooks, C. (2008). Introductory Econometrics for Finance. Cambridge: Cambridge University Press. https://doi.org/10.1017/CBO9780511841644

Central Bank of Nigeria (2018). Statistical Bulletin, 29.

Collignon, S. (2012). Fiscal Policy Rules and the Sustainability of Public Debt in Europe. International Economic Review, 53, 539-567. https://doi.org/10.1111/j.1468-2354.2012.00691.x

Dickey, D., \& Fuller, W. (1979). Likelihood Ratio Statistics for Autoregressive Time Series with a Unit Root. Econometrica, 49, 1057-1072. https://doi.org/10.2307/1912517

Doh-Nani, R. (2011). Is Ghana's Budget Deficit Sustainable? A Cointegration Analysis. M.Sc. Thesis, Kabwe: the Department of Economics, Kwame Nkrumah University of Science and Technology.

Engle, R., \& Granger, C. (1987). Cointegration and Error Correction Representation, Estimation and Testing. Econometrica, 55, 251-276. https://doi.org/10.2307/1913236

Ezeabasili, V. N., \& Mojekwu, J. N. (2011). Analysis of Fiscal and Deficits and Interest Rates in Nigeria. Journal of Economics and International Finance 3, 236-245.

Jibao, S. S., Schoeman, N. J., \& Naraidoo (2012). Fiscal Regime Changes and the Sustainability of Fiscal Imbalance in South Africa: A Smooth Transition Error-Correction Approach. South Africa Journal of Economics, 15, 112-127.

https://doi.org/10.4102/sajems.v15i2.179

Kuncoro, H. (2011). The Indonesia's State Budget Sustainability and Its Implication for Financial System Stability. Romanian Journal of Fiscal Policy, 2, 36-53.

Lusiyan, L., \& Thornton, J. (2009). The Sustainability of South African Fiscal Policy: An Historical Perspective. Applied Economics, 7, 859-868.

https://doi.org/10.1080/00036840701604537

Oshikoya, T. W., \& Tarawalie, A. (2010). Sustainability of Fiscal Policy: The West African Monetary Zone (WAMZ) Experience. Journal of Monetary and Economic Integration, 9, 1-29.

Oyeleke, O. J., \& Ajilore, O. T. (2014). Analysis of Fiscal Deficit Sustainability in Nigeria Economy: An Error Correction Approach. Asian Economic and Financial Review, 4, 199-210.

Quintos, C. E. (1995). Sustainability of the US Deficit Process with Structural Shifts. Journal of Business and Economic Statistics, 13, 409-417. https://doi.org/10.1080/07350015.1995.10524615

Saad, W. (2011). Assessing Sustainability of Lebanese Public Debt: A Cointegration Analysis Approach. International Research Journal of Finance and Economics, 62, 143-156.

Tshiaswak-Kashalala, G. (2006). Is Fiscal Policy Sustainable in South Africa? An Application of the Econometric Approach. University of Pretoria Working Paper, 2006-14.

Uwakwe, A. I. (2008). Public Debt Management and Fiscal Sustainability in Italy. American International University Bangladesh AIUB-Bus-Econ Working Paper Series, No. 2008-20. 